\title{
320 擬似テザーキャスティング制動制御の数值実験
}

\section{Control of Modeled Tether System with Casting Operation}

\author{
○西田 俊勝（山口大） \\ Toshikatsu NISHIDA, Yamaguchi University
}

小河原 加久治（山口大）

Kakuji OGAWARA, Yamaguchi University

Key Words: Space Robot, Manipulator, Delayed Feedback Control, Tether System, Casting Operation

\begin{abstract}
論文要旨＼cjkstart擬似テザーのキャスティングモデルに対する制御方法の確立を目的としたテザーキャスティングシステムの制動 制御に関寸る研究. マニピュレータのキャスティング動作を利用してテザー先端の子衛星を目的のポイント一誘導し， 静止させる力学運動を数値シミュレーションにより行い，最適な制御方法を研究する.
\end{abstract}

\section{1. はじめに}

近年の宇宙開発において, 宇宙開発プロジェクトの規模縮 小などにともない人工衛星，宇宙実験機，宇宙口ボットなど が小型化している傾向がある. 小型軽量化された宇宙機が宇 宙空間を移動する際の推進力を得るためにロクットエンジ ンやスラスタなどの推進器を使用するのは困難になってく る.燃料や推進薬を搭載するスペースが確保されにくくなる からである，そこで，母船に搭載されたマニピュレータと小 型宇宙機（以降，子衛星と呼ぶ）をテザーで連結したシステ ムが提案されている.このシステムを用いると，マニピュレ 一タのキャスティング動作を制御することによってテザー 先端の推進器を持たない子衛星を移動させることが可能と なる.

テザー（紐）の細く柔軟な性質は，リールに巻き取ること で長距離におよぶテザーをコンパクトに収納させたり、刪体 ロボットアームなどに比べてはるかに軽量なものであり，非 常に多くの利用価值が期待される. しかし, 無重力もしくは 微小重力の宇宙空間において,テザーシステムのキャスティ ング動作は非線形で不規則な動きとなる.このようなテザー の運動を解析するとき，たわみを考虑しない弦としてモデル 化することが多く行われている。しかし，実用テザーとして はワイヤーの周りを何重にも被覆したものや，網目状に編み こんであるものなどが提案されている。これらの素材はばね のような伸縮性や，大きなたわみをともなう動きをすると考 えられる.

そこでテザーを連続体ではなく，用体，ばね，ダンパから なる複数の微小要素を連結させた系（擬似テザー）として近 似し，そのキャスティングモデルにおいて遅延フィードバッ ク制御を用いた制動制御, 軌道制御に関する数值実験が中村 等によって行われている. 遅延フィードバック制御はカオス システムの不安定軌道制御を安定化する制御手法であり,こ れを用いた中村等の実験においてテザー先端の子衛星を静 止させられること，並びに軌道の安定化が可能であることが 確認されている。しかしその静止位置を任意に制御するまで には至っていない.

本研究では，遅延フィードバック制御を用いて大変形，大 変位をともなう擬似テザーに対して，宇宙空間を想定した場 での制動制御を行う，キャスティングを行ってから静止する までの時間を短縮すること,さらに子衛星を任意の位㯰に静 止させることを目標とする．以下，本研究の概要を示す．

2. キャスティングモデル
Fig.2-1 に示すようにマニピュレータ，テザー，子衛星から なるシステムを考える、テザーは $\mathrm{n}$ 個の質点をばねとダンパ で連結し, 各連結部の回転を自由とすることで大変形, 大変 位をともなう擬似テザーとして扱う．子衛星は剛体の球とす る.また, 㴊体のマニピュレータにのみ駆動トルク uが与え られるとする。

マニピュレータ, テザー要素の質点, 子衛星の質量をそれ ぞれ $\mathrm{m}_{\mathrm{m}}, \mathrm{m}_{\mathrm{i}}, \mathrm{m}_{\mathrm{s}}$, それぞれの状態を $\mathbf{X}_{\mathrm{m}}=\left[\mathrm{x}_{\mathrm{m}}, \mathrm{y}_{\mathrm{m}}, \theta_{\mathrm{m}}\right]^{\mathrm{T}}$, $\mathbf{X}_{\mathbf{i}}=\left[\mathbf{x}_{\mathrm{i}}, \mathbf{y}_{\mathrm{i}}\right]^{\mathrm{T}}(\mathrm{i}=1,2, \cdots, \mathrm{n}), \mathbf{X}_{\mathbf{s}}=\left[\mathbf{x}_{\mathbf{s}}, \mathbf{y}_{\mathrm{s}}, \theta_{\mathrm{s}}\right]^{\mathrm{T}}$ で表し, マニピュレ 一夕の長さを $1_{\mathrm{m}}$, 子衛星の半径を $\mathrm{l}_{\mathrm{s}}$ とする. また, マニピュ レータ, 各質点, 子衛星それぞれの間の距離を $\mathrm{d}_{\mathrm{i}}=\left[\mathrm{d}_{\mathrm{i}, \mathrm{x}}, \mathrm{d}_{\mathrm{i}, \mathrm{y}}\right]^{\mathrm{T}}$, 反力を $\mathbf{R}_{\mathbf{i}}=\left[\mathbf{R}_{\mathrm{i}, \mathrm{x}}, \mathbf{R}_{\mathrm{i}, \mathrm{y}}\right]^{\mathrm{T}} \quad(\mathrm{i}=0,2, \cdots, \mathrm{n})$ とする。ばね定数を $\mathrm{k}$, ダンパ定数を c で表す.

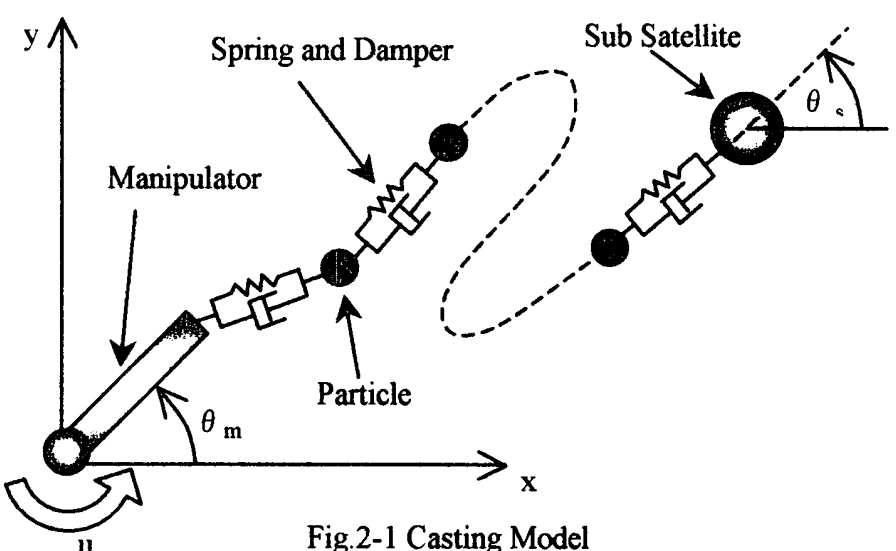

Fig.2-1 Casting Model

\section{2-1 運動方程式}

$\mathrm{i}$ 番目と $\mathrm{i}+1$ 番目の要素間の関係を Fig.2-2 に示す. $\mathbf{d}_{\mathbf{i}}$ は質 点 $\mathrm{i}$ と $\mathrm{i}+1$ の距離を表すべクトルで次のように求める.

$$
\mathbf{d}_{1}=\left[\begin{array}{l}
x_{i+1}-x_{i} \\
y_{i+1}-y_{i}
\end{array}\right]
$$

ばねの自然長を $\mathrm{k}_{0}$, 距離の伸び速度を $\mathbf{d}_{\mathbf{i}}$ とすると， $\mathbf{R}_{\mathbf{i}}$ は次 式で表される。

$$
\left|\mathbf{R}_{\mathbf{i}}\right|=\mathrm{k} \cdot\left(\left|\mathbf{d}_{\mathbf{i}}\right|-\mathbf{k}_{0}\right)^{3}+\mathrm{c} \cdot\left|\mathbf{d}_{\mathbf{i}}\right|
$$

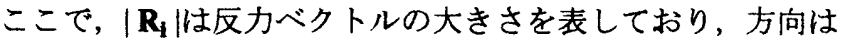
d と同じ方向である．以上のことから i 番目の質点に関する 
運動方程式を次のように表す。

$$
m_{i} \ddot{\mathbf{X}}_{\mathbf{i}}=\mathbf{R}_{\mathbf{i}}-\mathbf{R}_{\mathbf{i}-1}
$$

また, マニピュレータと子衛星の慣性モーメントを $\mathrm{I}_{\mathrm{m}}, \mathrm{I}_{\mathrm{s}}$ と するとこれらの運動方程式は次のように表される.

$$
\begin{aligned}
& \mathbf{M}_{m} \ddot{\mathbf{X}}_{\mathrm{m}}=\left[\begin{array}{c}
\mathbf{R}_{0} \\
\mathbf{r}_{\mathrm{m}} \times \mathbf{R}_{0}+\mathrm{u}
\end{array}\right] \\
& \mathbf{M}_{\mathrm{s}} \ddot{\mathbf{X}}_{\mathrm{s}}=\left[\begin{array}{c}
-\mathbf{R}_{\mathrm{n}} \\
\left(-\mathbf{r}_{\mathrm{s}}\right) \times\left(-\mathbf{R}_{\mathrm{n}}\right)
\end{array}\right]
\end{aligned}
$$

ただし, $\mathbf{M}_{\mathbf{m}}=\operatorname{diag}\left(\mathrm{m}_{\mathrm{m}}, \mathrm{m}_{\mathrm{m}}, \mathrm{I}_{\mathrm{m}}\right), \mathbf{M}_{\mathbf{s}}=\operatorname{diag}\left(\mathrm{m}_{\mathrm{s}}, \mathrm{m}_{\mathrm{s}}, \mathrm{I}_{\mathrm{s}}\right)$ は対角行列を 表し, $\mathbf{r}_{\mathrm{m}}=\left[\mathrm{l}_{\mathrm{m}} \cos \theta_{\mathrm{m}}, \mathrm{l}_{\mathrm{m}} \sin \theta_{\mathrm{m}}\right]^{\mathrm{T}}, \mathbf{r}_{\mathrm{s}}=\left[\mathrm{l}_{\mathrm{s}} \cos \theta_{\mathrm{s}}, \mathrm{l}_{\mathrm{s}} \sin \theta_{\mathrm{s}}\right]^{\mathrm{T}}$ はそれ ぞれの回転中心からばね，ダンパ結合部までの位置ベクトル を表す。

本研究では，(2.3)，(2.4）式を数值積分することで各時刻 における状態変数を算出する，以下に本研究で使用したキャ スティングモデルの物性値を示す.

Table.2-1 Physical-Properties Value

\begin{tabular}{|c|c|c|c|}
\hline & Mass $\mathrm{m}(\mathrm{kg})$ & Length $1(\mathrm{~m})$ & $\begin{array}{c}\text { Moment of } \\
\text { Inertia }\left(\mathrm{kg} \cdot \mathrm{m}^{2}\right)\end{array}$ \\
\hline Manipulator & 1.0 & 1.0 & $8.34 \times 10^{-2}$ \\
\hline Sub Satellite & $1.0 \times 10^{-2}$ & $5.0 \times 10^{-2}$ & $1.0 \times 10^{-4}$ \\
\hline Particles & $1.44 \times 10^{-4}$ & - & - \\
\hline \multicolumn{2}{|c|}{ Spring Constant k (N/m) } & $1.0 \times 10^{3}$ \\
\hline \multicolumn{2}{|c|}{ Natural Length of Spring ko $(\mathrm{m})$} & $1.0 \times 10^{-1}$ \\
\hline \multicolumn{2}{|c|}{ Damper Constant c $(\mathrm{N} \cdot \mathrm{s} / \mathrm{m})$} & $1.0 \times 10^{-1}$ \\
\hline
\end{tabular}

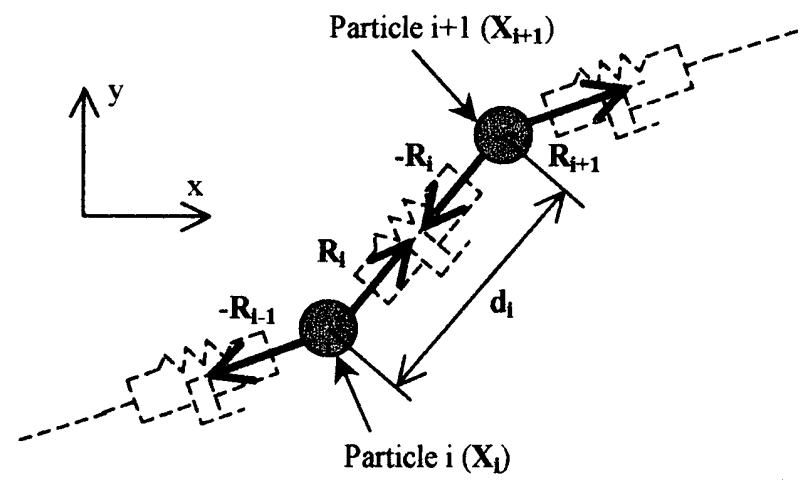

Fig. 2-2 Relations between the two Particles

\section{$2-2$ 目槱軌道の生成}

システムの状態変数は $\mathbf{X}_{\mathbf{m}}, \mathbf{X}_{\mathbf{i}}, \mathbf{X}_{\mathbf{s}}$ およでそれぞれの速度， 角速度である $\dot{\mathbf{X}}_{\mathbf{m}}, \dot{\mathbf{X}}_{\mathbf{i}}, \dot{\mathbf{X}}_{\mathbf{s}}$ のすべてが観測できることとする。 時刻 $\mathrm{t}$ におうける制御入力 $\mathrm{u}(\mathrm{t})$ を以下のように計算する。

$$
\mathrm{u}(\mathrm{t})=\mathrm{K}_{\mathrm{P}}\left(\theta_{\mathrm{D}}(\mathrm{t})-\theta_{\mathrm{m}}(\mathrm{t})\right)+\mathrm{K}_{\mathrm{D}}\left(\dot{\theta}_{\mathrm{D}}(\mathrm{t})-\dot{\theta}_{\mathrm{m}}(\mathrm{t})\right)
$$

これは目標角度 $\theta_{\mathrm{D}}(\mathrm{t})$ にマニピュレータの角度 $\theta_{\mathrm{m}}(\mathrm{t})$ を追従 させるような入力を加えている. なお各ゲイン $\mathrm{K}_{\mathrm{P}}, \mathrm{K}_{\mathrm{D}}$ は任 意とする.

マニピュレータを時刻 $\mathrm{t}$ から $\mathrm{t}+\Delta \mathrm{t}$ の間に $\theta_{\mathrm{m}}(\mathrm{t})$ から目標角 度 $\theta_{\mathrm{D}}(\mathrm{t})$ に移動させる軌道の生成には以下の 5 次多項式補間 を用いた.ただし境界条件における速度，加速度を零とする。

$$
\begin{aligned}
& \theta_{\mathrm{D}}(\mathrm{t})=\mathrm{a}_{0}+\mathrm{a}_{1} \mathrm{t}+\mathrm{a}_{2} \mathrm{t}^{2}+\mathrm{a}_{3} \mathrm{t}^{3}+\mathrm{a}_{4} \mathrm{t}^{4}+\mathrm{a}_{5} \mathrm{t}^{5} \\
& \text { ただし, } \mathrm{a}_{0}=\theta_{\mathrm{m}}, \mathrm{a}_{1}=\dot{\theta}_{\mathrm{m}}, \mathrm{a}_{2}=\frac{\ddot{\theta}_{\mathrm{m}}}{2} \\
& \mathrm{a}_{3}=\frac{20\left(\theta_{\mathrm{D}}-\theta_{\mathrm{m}}\right)-\left(8 \dot{\theta}_{\mathrm{D}}+12 \dot{\theta}_{\mathrm{m}}\right) \Delta \mathrm{t}+\left(\ddot{\theta}_{\mathrm{D}}-3 \ddot{\theta}_{\mathrm{m}}\right) \Delta \mathrm{t}^{2}}{2 \Delta \mathrm{t}^{3}} \\
& \mathrm{a}_{4}=\frac{-30\left(\theta_{\mathrm{D}}-\theta_{\mathrm{m}}\right)+\left(14 \dot{\theta}_{\mathrm{D}}+16 \dot{\theta}_{\mathrm{m}}\right) \Delta \mathrm{t}-\left(2 \ddot{\theta}_{\mathrm{D}}-3 \ddot{\theta}_{\mathrm{m}}\right) \Delta \mathrm{t}^{2}}{2 \Delta \mathrm{t}^{4}} \\
& \mathrm{a}_{5}=\frac{12\left(\theta_{\mathrm{D}}-\theta_{\mathrm{m}}\right)-6\left(\dot{\theta}_{\mathrm{D}}+\dot{\theta}_{\mathrm{m}}\right) \Delta \mathrm{t}+\left(\ddot{\theta}_{\mathrm{D}}-\ddot{\theta}_{\mathrm{m}}\right) \Delta \mathrm{t}^{2}}{2 \Delta \mathrm{t}^{5}}
\end{aligned}
$$

\section{3. 革延フィードバック制御}

遅延フィードバック制御は, カオスシステムの不安定軌道 制御をシステムのパラメータの微小恸動により安定化する 制御手法である. 周期 $\tau_{\mathrm{d}}$ の不安定周期軌道を安定化させる ために現時刻のパラメータと $\tau_{\mathrm{d}}$ 時刻前のパラメータの差を フィードバックに用いる. Fig.3-1 に遅延フィードバック制御 系の概要を示す.

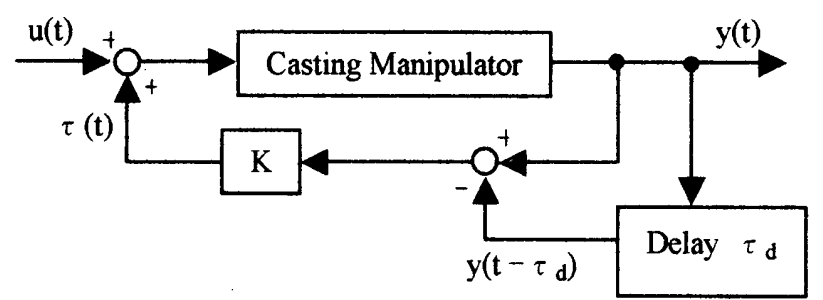

Fig.3-1 Block diagram of Delayed Feedback control system

遅延フィードバックによる制御入力を $\tau(\mathrm{t})$ とすると以下の 式で表される.

$$
\tau(\mathrm{t})=\mathrm{K}\left(\mathrm{y}(\mathrm{t})-\mathrm{y}\left(\mathrm{t}-\tau_{\mathrm{d}}\right)\right)
$$

K はゲイン行列であり，その値を理論的に定める方法はいま だ確立されておらず経験的に定められる.

遅延フィードバック制御は遅延時間を安定化に利用して いるため周期軌道をあらかじめ求める必要がなく，これが末 知である場合にも安定周期軌道への安定化が可能である特 徵がある。また，カオスシステムに限らず遅れ時間を有する システムや不安定系に対する安定化が可能であるなど様々 なシステムに対して有効であることが報告されている.

\section{4. おわりに}

本研究は，遅延フィードバック制御によって大変形，大変 位をともなう擬似テザーシステムの子衛星を任意の位置に 静止させる制動制御を行っている. そしてこの成果が宇宙環 境の高度利用につながることを期待する。

\section{考文献}

（1）小河原加久治・中村一平，遅延フィードバックによる擬 似テザーの制動制御，(現在投稿中）

(2) 能見公博・内山勝, キャスティングにおけるテザー宇宙 ロボットの運動制御，機論，66-647, C, (2000), 2255-2261 